\title{
Efficient synthesis of 2,3-dihydroquinazolin-4(1H)-ones using heterogeneous solid acid catalysts: unexpected formation of 2,3-dihydro-2-(4-(tetrahydro-2H-pyran-2-yloxy)butyl)quinazolin-4(1H)-one
}

\author{
Sandip B. Bharate,* Nagaraju Mupparapu, Sudhakar Manda, Jaideep B. Bharate, Ramesh \\ Mudududdla, Rammohan R. Yadav, and Ram A. Vishwakarma*
}

Medicinal Chemistry Division, Indian Institute of Integrative Medicine (Council of Scientific and Industrial Research), Canal Road, Jammu-180001, India

E-mail: sbharate@iiim.ac.in; ram@iiim.ac.in

\begin{abstract}
The heterogeneous solid acid catalysts Amberlyst-15 and silica- $\mathrm{HClO}_{4}$ displays efficient catalytic properties for the synthesis of 2,3-dihydroquinazolin-4(1H)-ones from anthranilamide and various aldehydes/ ketones under mild reaction conditions and in good yields. These catalysts also showed good catalytic activity for condensation of anthranilamide with a cyclic enol ether 3,4-dihydropyran and led to formation of new unexpected quinazolinone product 6 comprising two dihydropyran moieties. The new product $\mathbf{6}$ has been reported for the first time and is fully characterized using 2D-NMR data. Furthermore, both solid acid catalysts can be easily recycled without significant loss of activity.
\end{abstract}

Keywords: Aldehydes, Amberlyst-15, 2,3-dihydroquinazolin-4(1H)-ones, 3,4-dihydropyran, heterogeneous catalysis, ketones

\section{Introduction}

A large number of synthetic as well as natural 2,3-dihydroquinazolinone classes of fused heterocycles have been reported possessing a diverse range of biological activities. ${ }^{1-3}$ Due to their promising biological potential and wide occurrence in nature, several efforts have been made to develop an elegant approach for their synthesis. These include condensation of anthranilamide with aldehydes in presence of acid catalysts ${ }^{4,5}$ reductive cyclization of $O$ nitrobenzamide or $O$-azido-benzamide with aldehydes and ketones using $\mathrm{SmI}_{2},{ }^{6}$ or using $\mathrm{TiCl}_{4}{ }^{7}$, 8 reductive desulfurization of 2-thioxo-3H-quinazolin-4-ones with nickel boride in dry methanol, ${ }^{9}$ one-pot conversion from 2-nitro- $N$-arylbenzamides using $\mathrm{SnCl}_{2},{ }^{10}$ one-pot synthesis using p TSA, ${ }^{11}$ silica- $\mathrm{SO}_{3} \mathrm{H},{ }^{12}$ alum, ${ }^{13}$ montmorillonite $\mathrm{K}-10,{ }^{14}$ ionic liquids, ${ }^{15}$ and gallium(III) triflate, ${ }^{16}$ and enantioselective synthesis using chiral auxillary ${ }^{3}$ and Bronsted acid catalyst. ${ }^{17}$ Of these, the condensation of anthranilamide with aldehyde or ketone is one of the simplest and 
direct approach for preparation of 2,3-dihydroquinazolin-4(1H)-ones. Several researchers reported this approach using various catalysts such as $p \mathrm{TSA},{ }^{4}, 18$ cellulose- $\mathrm{SO}_{3} \mathrm{H}^{5}{ }^{5} \mathrm{TiCl}_{4},{ }^{7,8}$ $\mathrm{CuCl}_{2},{ }^{19} \mathrm{NH}_{4} \mathrm{Cl},{ }^{20}$ ionic liquids, ${ }^{15} \mathrm{TFA},{ }^{3}$ and chiral phosphonic acids. ${ }^{17,21}$

Limitations of the existing protocols realized in terms of longer reaction time, stringent conditions, homogeneous nature of catalysts (except cellulose- $\mathrm{SO}_{3} \mathrm{H}$ ) which makes the process very expensive, use of costly and water sensitive catalysts $\left(e . g . \mathrm{TiCl}_{4},{ }^{7,8}\right.$ ) and special efforts required to prepare the catalyst (e.g. cellulose- $\mathrm{SO}_{3} \mathrm{H}$ ). A recently reported eco-friendly approach $^{22}$ involving water as a reaction medium, requires refluxing conditions and is only faster and suitable for aromatic aldehydes. However, ketones and heterocyclic aldehydes require longer reaction times and producing lower yields. Inability of reaction for aromatic ketones is the major limitation of this strategy.

Heterogeneous catalysis ${ }^{5-23}$ has gained tremendous importance in organic synthesis due to its recyclability which makes cost-effective synthesis. Amberlyst- $15^{24}$ is a strongly acidic ionexchange resin developed particularly for heterogeneous acid catalysis of wide variety of organic reactions. It is also useful in non-aqueous ion-exchange systems for the removal of cationic impurities. Use of this catalyst has been reported for a variety of reactions such as Friedel-Craft reaction, ${ }^{25}$ glycosylation, ${ }^{26}$ deprotection of aromatic acetates, ${ }^{27}$ and also in multi-component synthesis of dihydroquinoxalin-2-amines from $O$-phenylene diamine, ketones and isocyanides. ${ }^{28}$ Similarly, silica- $\mathrm{HClO}_{4}$ has also been used in various organic reactions like acylation of phenols, thiols etc. ${ }^{29}$ However no report exist on use of these two solid acid catalysts for the preparation of 2,3-dihydroquinazolin-4(1H)-ones.

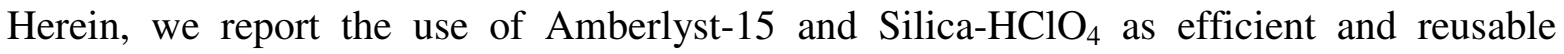
catalysts for synthesis of 2,3-dihydroquinazolin-4(1H)-ones 3 in shorter reaction time under mild reaction conditions (Figure 1). Furthermore, the ability of these catalysts for formation of anthranilamide - 2,3-dihydropyran condensation product has also been reported in the present paper. Developed protocol provides easy and economical access to biologically important dihydroquinazolin-4(1H)-one scaffold for a drug discovery program.<smiles>NC(=O)c1ccccc1N</smiles>

1

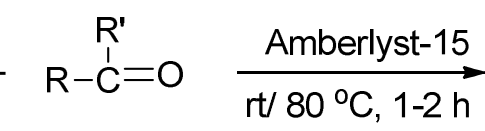

2

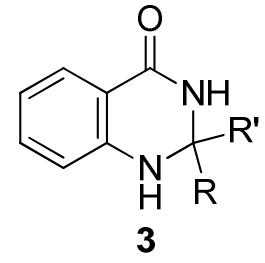

3

Figure 1. Condensation of anthranilamide (1) with aldehydes/ ketones 2.

\section{Results and Discussion}

The model reaction between anthranilamide (1) and benzaldehyde was selected to investigate catalytic efficiency of different solid acid catalysts viz. Amberlyst-15 along with few other cation-exchange resins, silica gel and silica- $\mathrm{HClO}_{4}$ (Table 1, entries 1-6). Based on the earlier 
reports, acetonitrile ${ }^{5}$ and water $^{22}$ were chosen for optimization study. No product was formed in the absence of catalyst either in acetonitrile or water up to $6 \mathrm{~h}$ of reaction time. No improvement was observed even after addition of molecular sieves $\left(4^{\circ} \mathrm{A}\right)$. Further, with the use of Amberlyst15 or Amberlite-IRA-40 as catalysts and acetonitrile as a solvent resulted in complete conversion of starting materials to desired product with $>85 \%$ isolated yield. Amberlyst-15 and silicaperchloric acid showed good catalytic ability compared with other catalysts. We performed further optimization for Amberlyst-15. Reaction when performed in presence of Amberlyst-15 in water resulted in formation of desired product in $60 \%$ yield. The amberlite-IRC-50 and silica gel were found to be inefficient in promoting the reaction rate. Amberlyst-15 in acetonitrile as a solvent was found to be more efficient and thus selected for further optimization studies.

Table 1. Reaction between anthranilamide (1) and benzaldehyde (2c) in presence of various catalysts $^{\mathrm{a}}$

\begin{tabular}{|c|c|c|c|}
\hline Entry & Catalyst $(\% \mathrm{w} / \mathrm{w})^{\mathrm{b}}$ & Reaction conditions & Yield $^{\mathrm{c}}(\%)$ \\
\hline 1 & Amberlite-IRC-50 (50) & $\mathrm{ACN}, \mathrm{rt}, 1 \mathrm{~h}$ & 0 \\
\hline 2 & Amberlite-IRA-400 (50) & $\mathrm{ACN}, \mathrm{rt}, 1 \mathrm{~h}$ & 60 \\
\hline 3 & Amberlite-IRA-40 (50) & $\mathrm{ACN}, \mathrm{rt}, 6 \mathrm{~h}$ & 85 \\
\hline 4 & Amberlyst-15 (50) & $\mathrm{ACN}, \mathrm{rt}, 1 \mathrm{~h}$ & 92 \\
\hline 5 & Amberlyst-15 (50) & $\mathrm{H}_{2} \mathrm{O}, \mathrm{rt}, 1 \mathrm{~h}$ & 60 \\
\hline 6 & Silica- $\mathrm{HClO}_{4}(50)$ & $\mathrm{ACN}, \mathrm{rt}, 45 \mathrm{~min}$ & 92 \\
\hline 7 & Amberlyst-15 (10) & $\mathrm{ACN}, \mathrm{rt}, 45 \mathrm{~min}$ & 30 \\
\hline 8 & Amberlyst-15 (20) & $\mathrm{ACN}, \mathrm{rt}, 45 \mathrm{~min}$ & 42 \\
\hline 9 & Amberlyst-15 (30) & $\mathrm{ACN}, \mathrm{rt}, 45 \mathrm{~min}$ & 65 \\
\hline 10 & Amberlyst-15 (40) & $\mathrm{ACN}, \mathrm{rt}, 45 \mathrm{~min}$ & 80 \\
\hline 11 & Amberlyst-15 (50) & $\mathrm{ACN}, \mathrm{rt}, 45 \mathrm{~min}$ & 90 \\
\hline 12 & Amberlyst-15 (10) & $\mathrm{ACN}, \mathrm{rt}, 4 \mathrm{~h}$ & 85 \\
\hline 13 & Amberlyst-15 (20) & $\mathrm{ACN}, \mathrm{rt}, 3 \mathrm{~h}$ & 85 \\
\hline 14 & Amberlyst-15 (30) & $\mathrm{ACN}, \mathrm{rt}, 2.5 \mathrm{~h}$ & 85 \\
\hline 15 & Amberlyst-15 (40) & $\mathrm{ACN}, \mathrm{rt}, 2 \mathrm{~h}$ & 90 \\
\hline 16 & Amberlyst-15 (10) & $\mathrm{MS},{ }^{\mathrm{d}} \mathrm{ACN}, \mathrm{rt}, 3.5 \mathrm{~h}$ & 85 \\
\hline 17 & Amberlyst-15 (50) & $\mathrm{MS},{ }^{\mathrm{d}} \mathrm{ACN}, \mathrm{rt}, 0.5 \mathrm{~h}$ & 90 \\
\hline
\end{tabular}

${ }^{\text {a }} 50 \% \mathrm{w} / \mathrm{w}$ catalyst was used in this study.

${ }^{\mathrm{b}}$ Weight percentage of catalyst with respect to anthranilamide

${ }^{c}$ the isolated yield after chromatography.

${ }^{\mathrm{d}} \mathrm{MS}$, molecular sieves $\left(4^{\circ} \mathrm{A}\right)$.

Next, we studied the effect of amount of catalyst on the efficient completion of the reaction. Different weight $\%$ of the catalyst was used and the percentage conversion after different time intervals was monitored (Table 1, entries 7-17). Results obtained here indicate that the efficiency 
of the reaction (higher yield) increased when a higher amount of the catalyst is used. The percent yield of the reaction increases from 30 to $90 \%$ with increasing the amount of catalyst from 10 $\% \mathrm{w} / \mathrm{w}$ to $50 \% \mathrm{w} / \mathrm{w}$ at $45 \mathrm{~min}$ reaction time. However, the reaction went to complete conversion using $10 \% \mathrm{w} / \mathrm{w}$ of the catalyst after $4 \mathrm{~h}$ of reaction time and the isolated yield was also excellent. Among various amounts of catalysts used, the $50 \% \mathrm{w} / \mathrm{w}$ was found to be highly active and more efficient with respect to reaction time. The $50 \% \mathrm{w} / \mathrm{w}$ catalyst afforded complete conversion of reaction within 45 min time. Further with the addition of molecular sieves $\left(4^{\circ} \mathrm{A}\right)$ to promote the rate of reaction, there was not significant decrease in the reaction time.

Recyclability of Amberlyst-15 was checked to prove the heterogeneous nature and its repeated use. The treatment of anthranilamide $(\mathbf{1}, 1 \mathrm{mmol})$ with benzaldehyde $(2 \mathrm{c}, 1 \mathrm{mmol})$ in presence of Amberlyst-15 led to formation of desired 2-phenyl-2,3-dihydroxyquinazolin-4-one 3c with complete consumption of starting materials in $45 \mathrm{~min}, 4 \mathrm{~h}, 8 \mathrm{~h}$ and $12 \mathrm{~h}$ over four cycles respectively. Similarly Silica- $\mathrm{HClO}_{4}$ also showed excellent recyclability. Thus it is noteworthy to mention that these catalysts could be recycled several times, although there is increased reaction time after each cycle. ${ }^{25}$

Next, we studied the scope of the reaction. As expected, this reaction proceeded smoothly and the desired products were obtained in excellent yields. A series of aldehydes with either electron-donating or electron-withdrawing groups attached to the aromatic ring were investigated (Table 2). The substitution groups on the aromatic ring had no obvious effect on the reaction yield. Aliphatic (Table 2, entries 'a' and 'b'), aromatic (Table 2, entries 'c-l') as well as heteroaromatic aldehydes (Table 2, entries 'm-o') produced desired products in good yields. Similarly several aliphatic (Table 2, entries 'p-r') as well as aromatic ketones (Table 2, entry 's') participated well in this reaction. Reaction of 3-formyl indole (2n) with anthranilamide (3) when performed under reflux conditions for 45 min using Amberlyst-15 and silica- $\mathrm{HClO}_{4}$, it was observed that yield of the product 3n was improved (75 and 85\% respectively). Similarly, for quinoline substituted compound 3o, higher yield was obtained using silica- $\mathrm{HClO}_{4}$ catalyst under heating condition.

Aromatic ketones were found to be less reactive compared to aliphatic or alicyclic ketones. ${ }^{22}$ Reaction of 1 with acetophenone (entry ' $s$ ') when performed at room temperature, desired product was obtained in only 35\% yield; however under refluxing condition for $90 \mathrm{~min}, 70 \%$ yield of 3s was obtained. For this reaction, silica- $\mathrm{HClO}_{4}$ produced similar yield (78\%). All synthesized compounds were stable and were fully characterized by NMR, MS and melting point analysis. Compounds 3j, 3n and $\mathbf{3 o}$ are new compounds and have been synthesized for the first time. One of our synthesized compound $\mathbf{3 l}$ (naphtha-1-yl analog) is reported to possess in vivo anti-leukemic activity as well as tubulin polymerization inhibitory activity $\left(\mathrm{IC}_{50} 1.7 \mu \mathrm{M}\right) .^{30,31}$ 
Table 2. Amberlyst-15 catalyzed synthesis of 2,3-dihydroquinazolin-4(1H)-ones ${ }^{\mathrm{a}} 3$ via scheme shown in Figure 1

\begin{tabular}{|c|c|c|c|c|c|c|c|c|}
\hline \multirow{2}{*}{ Entry } & \multicolumn{2}{|c|}{ Aldehyde/ Ketone, $\mathbf{2}$} & \multicolumn{2}{|c|}{ Product } & \multirow{2}{*}{$\begin{array}{l}\text { Time } \\
(\min )\end{array}$} & \multirow{2}{*}{$\begin{array}{c}\text { Yield }^{b} \\
(\%)\end{array}$} & \multicolumn{2}{|c|}{$\mathrm{mp}\left({ }^{\circ} \mathrm{C}\right)$} \\
\hline & $\mathrm{R}$ & $\mathrm{R}^{\prime}$ & Structure & Code & & & Found & Reported \\
\hline $\mathrm{a}$ & $-\mathrm{CH}_{3}$ & $-\mathrm{H}$ & & $3 \mathbf{a}$ & 60 & 80 & $\begin{array}{l}137- \\
140\end{array}$ & $n r^{\mathrm{d}}$ \\
\hline $\mathrm{b}$ & $-\mathrm{CH}_{2} \mathrm{CH}_{2} \mathrm{CH}_{3}$ & $-\mathrm{H}$ & & $3 \mathbf{b}^{5,20}$ & 60 & 75 & $\begin{array}{l}160- \\
162\end{array}$ & $\begin{array}{l}162- \\
164^{20}\end{array}$ \\
\hline $\mathrm{c}$ & & $-\mathrm{H}$ & & $\mathbf{3 c}^{16,17,20,32}$ & 60 & 85 & $\begin{array}{l}213- \\
215\end{array}$ & $\begin{array}{l}218- \\
219^{16}\end{array}$ \\
\hline d & & $-\mathrm{H}$ & & $3 \mathbf{d}^{17}$ & 45 & 90 & $\begin{array}{l}213- \\
215\end{array}$ & $215.8^{17}$ \\
\hline $\mathrm{e}$ & & $-\mathrm{H}$ & & $\mathbf{3} \mathbf{e}^{5,16,32}$ & 60 & 75 & $\begin{array}{l}200- \\
202\end{array}$ & $\begin{array}{l}198- \\
200^{22}\end{array}$ \\
\hline $\mathrm{f}$ & & $-\mathrm{H}$ & & $\mathbf{3 f}^{16,17}$ & 60 & 85 & $\begin{array}{l}280- \\
282\end{array}$ & $\begin{array}{l}278- \\
280^{16}\end{array}$ \\
\hline g & & $-\mathrm{H}$ & & $3 \mathbf{g}^{17}$ & 45 & 80 & $\begin{array}{c}182- \\
184\end{array}$ & $184.8^{17}$ \\
\hline $\mathrm{h}$ & & $-\mathrm{H}$ & & $3 \mathbf{h}^{33}$ & 60 & 85 & $\begin{array}{l}222- \\
225\end{array}$ & $n r^{d}$ \\
\hline $\mathrm{i}$ & & $-\mathrm{H}$ & & $\mathbf{3 i}^{5,16,32}$ & 60 & 85 & $\begin{array}{l}203- \\
205\end{array}$ & $\begin{array}{c}206- \\
207^{16,22}\end{array}$ \\
\hline $\mathrm{j}$ & & $-\mathrm{H}$ & & $3 \mathbf{j}^{\mathrm{c}}$ & 60 & 85 & $\begin{array}{l}243- \\
246\end{array}$ & $\mathrm{nr}^{\mathrm{d}}$ \\
\hline
\end{tabular}


Table 2. Continued

\begin{tabular}{|c|c|c|c|c|c|c|c|c|}
\hline \multirow{2}{*}{ Entry } & \multicolumn{2}{|c|}{ Aldehyde/ Ketone, 2} & \multicolumn{2}{|c|}{ Product } & \multirow{2}{*}{$\begin{array}{l}\text { Time } \\
\text { (min) }\end{array}$} & \multirow{2}{*}{$\begin{array}{c}\text { Yield }^{\mathrm{b}} \\
(\%)\end{array}$} & \multicolumn{2}{|c|}{$\mathrm{mp}\left({ }^{\circ} \mathrm{C}\right)$} \\
\hline & $\mathrm{R}$ & $\mathrm{R}^{\prime}$ & Structure & Code & & & Found & Reported \\
\hline $\mathrm{k}$ & & $-\mathrm{H}$ & & $3 \mathbf{k}^{17}$ & 60 & 70 & $\begin{array}{l}200- \\
203\end{array}$ & $201^{17}$ \\
\hline 1 & & $-\mathrm{H}$ & & $31^{30}$ & 60 & 75 & $\begin{array}{c}173- \\
175\end{array}$ & $n r^{\mathrm{d}}$ \\
\hline $\mathrm{m}$ & & $-\mathrm{H}$ & & $3 \mathbf{m}^{5,16}$ & 60 & 75 & $\begin{array}{l}160- \\
163\end{array}$ & $\begin{array}{c}163-165^{1} \\
16,22\end{array}$ \\
\hline $\mathrm{n}$ & & $-\mathrm{H}$ & & $3 n^{c}$ & 90 & 65 & $\begin{array}{l}227- \\
230\end{array}$ & nrd \\
\hline o & & $-\mathrm{H}$ & & $30^{c}$ & 120 & 55 & $\begin{array}{l}272- \\
274\end{array}$ & $\mathrm{nr}^{\mathrm{d}}$ \\
\hline $\mathrm{p}$ & $-\mathrm{CH}_{3}$ & $\begin{array}{c}- \\
\mathrm{CH}_{3}\end{array}$ & & $\mathbf{3} \mathbf{p}^{34}$ & 60 & 75 & $\begin{array}{c}179- \\
182\end{array}$ & $\begin{array}{l}182- \\
183^{34}\end{array}$ \\
\hline$q$ & $-\mathrm{CH}_{2} \mathrm{CH}_{3}$ & $\begin{array}{c}- \\
\mathrm{CH}_{2} \\
\mathrm{CH}_{3}\end{array}$ & & $\mathbf{3} \mathbf{q}^{8,35}$ & 60 & 75 & $\begin{array}{l}197- \\
200\end{array}$ & $\mathrm{nr}^{\mathrm{d}}$ \\
\hline $\mathrm{r}$ & & & & $3 \mathbf{r}^{5,20,34}$ & 60 & 70 & $\begin{array}{l}215- \\
217\end{array}$ & $\begin{array}{l}217- \\
219^{20}\end{array}$ \\
\hline $\mathrm{s}^{\mathrm{e}}$ & & $\mathrm{CH}_{3}$ & & $3 \mathbf{s}^{22}$ & 120 & 70 & $\begin{array}{l}218- \\
221\end{array}$ & $\begin{array}{l}222- \\
224^{22}\end{array}$ \\
\hline
\end{tabular}

${ }^{a}$ All products were characterized by NMR and MS data.

${ }^{\mathrm{b}}$ Yields refer to pure products after silica gel column chromatography.

${ }^{\mathrm{c}}$ New compounds.

${ }^{\mathrm{d}}$ Melting point not reported (nr) or not available in the literature

${ }^{\mathrm{e}}$ Reaction was performed under reflux condition. 
These promising results prompted us to study catalytic efficiency of Amberlyst-15 for condensation of anthranilamide with cyclic enol ether. The reaction of 1 with 3,4-dihydropyran (4) in ACN in presence of Amberlyst-15 (50\% w/w) at $80{ }^{\circ} \mathrm{C}$ did not led to formation of expected product 5 (reported by Reddy et $a l$ ) $;^{5}$ however an unexpected product $\mathbf{6}$ was formed (60\% yield; Figure 2). The product 6 was also formed in room temperature reaction but only in $30 \%$ yield. The ${ }^{1} \mathrm{H}$ NMR data of sulphonamide analog of $\mathbf{5}$ provided in Reddy et al.'s paper ${ }^{5}$ contain a triplet at $\delta 4.69 \mathrm{ppm}$ for terminal methylene protons $\left(-\mathrm{CH}_{2}-\mathrm{CH}_{2} \mathrm{OH}\right)$ of side chain. As per our knowledge, such a downfield chemical shift value for these type of protons have never been encountered in the literature.

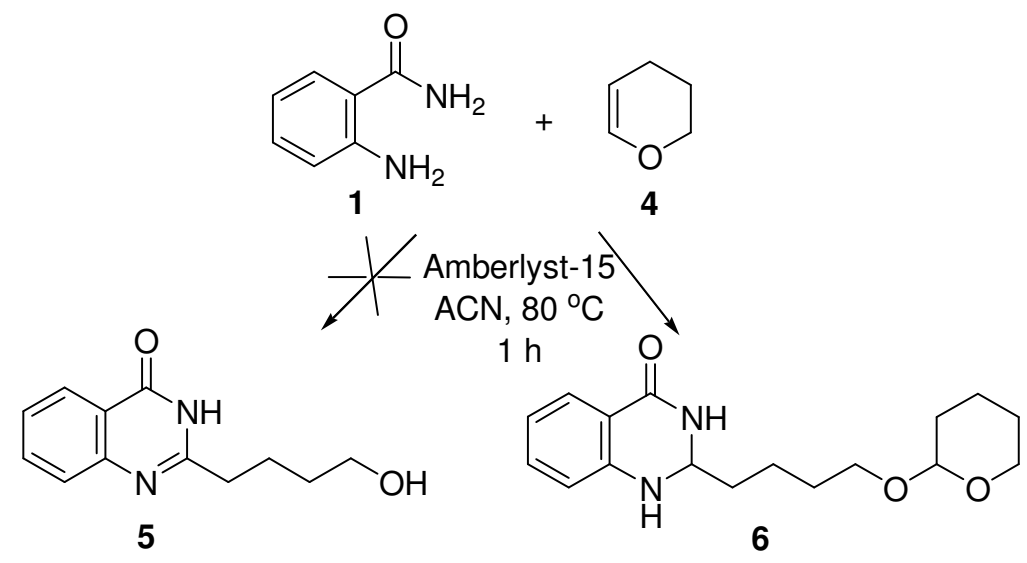

Figure 2. Reaction between anthranilamide (1) and 2,3-dihydropyran (4).

The ${ }^{1} \mathrm{H}$ NMR spectrum of our 3,4-dihydropyran condensed product showed unexpected peaks at $4.92(\mathrm{t}, 1 \mathrm{H}), 4.56(\mathrm{t}, 1 \mathrm{H}), 3.58-3.42(\mathrm{~m}, 2 \mathrm{H})$ and extra 6 protons in $\delta 1-2$ ppm region. ${ }^{13} \mathrm{C}$ NMR also showed similar observation with a presence of several extra signals in aliphatic region. DEPT-135 spectrum showed total $8 \mathrm{CH}_{2}$ 's, two of which are in the 60-70 ppm region and two $\mathrm{CH}$ in non-aromatic region (99.3 and $65.3 \mathrm{ppm})$. Aromatic region showed four $\mathrm{Ar}-\mathrm{CH}$ $(133.8,128.6,119.3,114.7 \mathrm{ppm})$ and three quaternary carbons $(165.3,147.4,116.1 \mathrm{ppm})$ (see supplementary material). NMR information pointed towards presence of additional pyran ring. Further MS data $\left(\mathrm{m} / \mathrm{z} 327[\mathrm{M}+\mathrm{Na}]^{+}\right)$supported NMR results. The location of attachment of a second pyran moiety, whether on $\mathrm{NH}$ or terminal $\mathrm{OH}$, was confirmed by HMBC/HSQC correlations. In HMBC spectrum, the additional $\mathrm{CH}$ peak $\left({ }^{1} \mathrm{H} \mathrm{NMR}: \delta 4.56 \mathrm{ppm}\right)$ have not shown any correlation with either carbonyl or any aromatic carbon, ruling out the possibility of second pyran moiety linked to NH. The key HMBC correlations of compound $\mathbf{6}$ are shown in supporting information (Figure S5). Furthermore, extreme downfield $\mathrm{CH}$ signal $\left(\delta 99.3 \mathrm{ppm}\right.$ ) in ${ }^{13} \mathrm{C}$ NMR confirmed O-C $\mathrm{H}-\mathrm{O}$ pattern. The combined spectral information of ${ }^{1} \mathrm{H},{ }^{13} \mathrm{C}$, DEPT, MS, HMBC/HSQC NMR data led to structure 6. Further, this type of protection of primary alcohols using tetrahydropyran has been reported earlier under acidic conditions. ${ }^{36}$ 
Results clearly indicate the heterogeneous nature of the catalyst with good recycling capability. The macroreticular pore structure of Amberlyst-15 permits ready access of liquid or gaseous reactants to the hydrogen ion sites located throughout the bead, thus ensuring successful performance even in non-swelling organic media. Amberlyst-15 is an inexpensive and nonhazardous commercially available solid acid catalyst. It can be easily handled and separated from the reaction mixtures by simple filtration. The recovered catalyst can be reused over more than three cycles without significant loss of catalytic activity.

\section{Conclusions}

An efficient protocol for synthesis of 2,3-dihydroquinazolin-4(1H)-ones using solid acid catalysts Amberlyst-15 and silica- $\mathrm{HClO}_{4}$ as recyclable catalysts in shorter reaction times and high yields under milder reaction conditions has been described. Furthermore, the catalytic efficiency of these catalysts was also studied for cyclic enol ether 3,4-dihydropyran and the formation of 2,3-dihydro-2-(4-(tetrahydro-2 $H$-pyran-2-yloxy)butyl)quinazolin-4( $1 H$ )-one (6) product has been reported for the first time. Catalyst being inexpensive, non-hazardous and heterogeneous in nature makes the method economically viable for the synthesis of titled compounds.

\section{Experimental Section}

General. All chemicals were obtained from Sigma-Aldrich Company and used as received. NMR spectra were recorded on a Brucker-Avance DPX FT-NMR $400 \mathrm{MHz}$ instrument. Mass spectra were recorded on an Agilent 1100 LC-Q-TOF. Elemental analyses were recorded on an Elementar Vario EL III and melting points were recorded on a digital melting point apparatus.

Synthesis of 2,3-dihydroquinazolin-4(1H)-ones 3 and 6. Amberlyst-15 (50\%w/w with respect to 1) was added to a solution of anthranilamide $(\mathbf{1}, 1 \mathrm{mmol})$ and aldehyde/ ketone/3,4dihydropyran ( 2 or $4,1.0 \mathrm{mmol}$ ) in acetonitrile $(5 \mathrm{~mL})$. The mixture was stirred at room temperature $/ 80{ }^{\circ} \mathrm{C}$ for the specified period of time. The progress of the reaction was monitored by TLC. After completion, the reaction mixture was then allowed to cool to room temperature and filtered. Filtrate was concentrated and purified by silica-gel column chromatography to get products 3a-s and 6. Characterization data for new compounds is provided below:

2,3-Dihydro-2-(4-hydroxy-3-nitrophenyl)-quinazolin-4(1H)-one (3j). Yellow solid; yield: 85\%; mp 243-246 ${ }^{\circ} \mathrm{C} .{ }^{1} \mathrm{H}$ NMR (400 MHz, DMSO- $\left.d_{6}\right): \delta(\mathrm{ppm}) 8.31(\mathrm{~s}, 1 \mathrm{H}), 7.99(\mathrm{~s}, 1 \mathrm{H}), 7.68$ $(\mathrm{d}, J 6.8 \mathrm{~Hz}, 1 \mathrm{H}), 7.62(\mathrm{~d}, J 6.4 \mathrm{~Hz}, 1 \mathrm{H}), 7.28(\mathrm{t}, J 7.2 \mathrm{~Hz}, 1 \mathrm{H}), 7.14(\mathrm{~m}, 2 \mathrm{H}), 6.76(d, J 8.0 \mathrm{~Hz}$, $1 \mathrm{H}), 6.72(\mathrm{t}, J 7.2 \mathrm{~Hz}, 1 \mathrm{H}), 5.78(\mathrm{~s}, 1 \mathrm{H}) .{ }^{13} \mathrm{C}$ NMR (100 MHz, DMSO- $\left.d_{6}\right): \delta(\mathrm{ppm}) 163.4,152.1$, 147.5, 136.2, 133.6, 133.4, 132.7, 127.3, 123.5, 119.1, 117.3, 114.8, 114.4, 65.2; MS (Q-TOF): 
$m / z 286[\mathrm{M}+1]^{+}, 308[\mathrm{M}+\mathrm{Na}]^{+}$. analysis for $\mathrm{C}_{14} \mathrm{H}_{11} \mathrm{~N}_{3} \mathrm{O}_{4}(285.07)$, calcd, C, 58.95; H, 3.89; N, 14.73; found, C, 59.13; H, 3.98; N, 14.82 .

2,3-Dihydro-2-(naphthalene-1-yl)quinazolin-4(1H)-one (31). White solid: Yield: 85\%; mp 173-175 ${ }^{\circ} \mathrm{C} .{ }^{1} \mathrm{H}$ NMR (400 MHz, DMSO- $\left.d_{6}\right): \delta(\mathrm{ppm}) 8.56(\mathrm{~d}, J 6.8 \mathrm{~Hz}, 1 \mathrm{H}), 8.27(\mathrm{~s}, 1 \mathrm{H}), 7.98$ (t, J $8.4 \mathrm{~Hz}, 2 \mathrm{H}), 7.70(\mathrm{t}, J 6.4 \mathrm{~Hz}, 2 \mathrm{H}), 7.57(\mathrm{~m}, 3 \mathrm{H}), 7.26(\mathrm{t}, J 7.6 \mathrm{~Hz}, 1 \mathrm{H}), 7.08(\mathrm{~s}, 1 \mathrm{H}), 6.74$ $(\mathrm{dd}, J 8.0,12.8 \mathrm{~Hz}, 2 \mathrm{H}), 6.49(\mathrm{~s}, 1 \mathrm{H}) .{ }^{13} \mathrm{C} \mathrm{NMR}\left(100 \mathrm{MHz}, \mathrm{DMSO}-d_{6}\right): \delta(\mathrm{ppm}) 163.9,148.3$, 135.1, 133.7, 133.2, 130.4, 129.2, 128.5, 127.4, 126.0, 125.7, 125.1, 124.4, 117.2, 114.9, 114.4, 65.8; MS (Q-TOF): $\mathrm{m} / z 275[\mathrm{M}+1]^{+}, 297[\mathrm{M}+\mathrm{Na}]^{+}$. analysis for $\mathrm{C}_{18} \mathrm{H}_{14} \mathrm{~N}_{2} \mathrm{O}$ (274.11), calcd, C, 78.81; H, 5.14; N, 10.21; found, C, 78.62; H, 5.27; N, 10.03 .

2,3-Dihydro-2-(1H-indol-3-yl)quinazolin-4(1H)-one (3n). Light yellow crystalline solid; yield: 75\%; mp 227-230 ${ }^{\circ} \mathrm{C} .{ }^{1} \mathrm{H}$ NMR (400 MHz, DMSO- $\left.d_{6}\right): \delta(\mathrm{ppm}) 8.08$ (s, 1H), 7.77 (d, $J 8.0 \mathrm{~Hz}$, 1H), $7.67(\mathrm{~d}, J 7.8 \mathrm{~Hz}, 1 \mathrm{H}), 7.40(\mathrm{~m}, 2 \mathrm{H}), 7.22(\mathrm{t}, J 7.6 \mathrm{~Hz}, 1 \mathrm{H}), 7.09$ (t, $J 7.6 \mathrm{~Hz}, 1 \mathrm{H}), 7.02(\mathrm{t}, J$ $6.8 \mathrm{~Hz}, 1 \mathrm{H}), 6.92(\mathrm{~s}, 1 \mathrm{H}), 6.76(\mathrm{~d}, J 8.0 \mathrm{~Hz}, 1 \mathrm{H}), 6.69(\mathrm{t}, J 7.2 \mathrm{~Hz}, 1 \mathrm{H}), 6.03(\mathrm{~s}, 1 \mathrm{H}) .{ }^{13} \mathrm{C} \mathrm{NMR}$ (100 MHz, DMSO- $\left.d_{6}\right): \delta(\mathrm{ppm}) 164.7,149.2,137.1,133.5,127.9,125.8,125.1,121.9,120.4$, 119.2, 117.4, 115.7, 114.9, 112.1, 62.1; MS (Q-TOF): $\mathrm{m} / \mathrm{z} 264[\mathrm{M}+1]^{+}, 286[\mathrm{M}+\mathrm{Na}]^{+}$. analysis for $\mathrm{C}_{16} \mathrm{H}_{13} \mathrm{~N}_{3} \mathrm{O}$ (263.11), calcd, C, 72.99; H, 4.98; N, 15.96; found, C, 73.07; H, 5.02; N, 15.71 .

2,3-Dihydro-2-(quinolin-3-yl)quinazolin-4(1H)-one (3o). Yellow solid; yield: $80 \%$. mp 272$274{ }^{\circ} \mathrm{C} .{ }^{1} \mathrm{H}$ NMR (400 MHz, DMSO- $\left.d_{6}\right): \delta(\mathrm{ppm}) 9.06(\mathrm{~s}, 1 \mathrm{H}), 8.47$ (s, 1H), $8.40(\mathrm{~s}, 1 \mathrm{H}), 8.04(\mathrm{t}$, $J 8.0 \mathrm{~Hz}, 2 \mathrm{H}), 7.82(\mathrm{~m}, 1 \mathrm{H}), 7.79(\mathrm{~m}, 2 \mathrm{H}), 7.29(\mathrm{dd}, J 7.2,14.0 \mathrm{~Hz}, 1 \mathrm{H}), 6.79(\mathrm{~d}, J 8.4 \mathrm{~Hz}, 2 \mathrm{H})$,

$6.75(\mathrm{t}, J 7.2 \mathrm{~Hz}, 1 \mathrm{H}), 6.06(\mathrm{~s}, 1 \mathrm{H}) .{ }^{13} \mathrm{C}$ NMR (100 MHz, DMSO- $\left.d_{6}\right): \delta(\mathrm{ppm}) 163.5,149.9$, 147.6, 147.4, 133.9, 133.8, 133.4, 129.8, 128.5, 128.2, 127.4, 127.0, 117.5, 115.0, 114.5, 64.9; MS (Q-TOF): $m / z 276[\mathrm{M}+1]^{+}, 298[\mathrm{M}+\mathrm{Na}]^{+}$; analysis for $\mathrm{C}_{17} \mathrm{H}_{13} \mathrm{~N}_{3} \mathrm{O}$ (275.11), calcd, C, 74.17; $\mathrm{H}, 4.76$; N, 15.26; found, C, 73.68; H, 4.91; N, 15.18 .

2,3-Dihydro-2-(4-(tetrahydro-2H-pyran-2-yloxy)butyl) quinazolin-4(1H)-one (6). Yellow oil; yield: 60\%. ${ }^{1} \mathrm{H}$ NMR (400 MHz, $\mathrm{CDCl}_{3}$ ): $\delta$ (ppm) 7.87 (d, J $\left.6.4 \mathrm{~Hz}, 1 \mathrm{H}\right), 7.32$ (t, $J 6.8 \mathrm{~Hz}$, $1 \mathrm{H}), 6.87(\mathrm{t}, J 7.2 \mathrm{~Hz}, 1 \mathrm{H}), 6.67(\mathrm{~d}, J 8.0 \mathrm{~Hz}, 1 \mathrm{H}), 6.31$ (brs, $\mathrm{D}_{2} \mathrm{O}$ exchangeable, NH), 4.92 (t, $J$ $5.6 \mathrm{~Hz}, 1 \mathrm{H}), 4.56(\mathrm{t}, J 4.4 \mathrm{~Hz}, 1 \mathrm{H}), 3.89-3.74(\mathrm{~m}, 2 \mathrm{H}), 3.58-3.42(\mathrm{~m}, 2 \mathrm{H}), 1.89-1.62(\mathrm{~m}, 6 \mathrm{H})$, 1.60-1.45 (m, 6H). ${ }^{13} \mathrm{C}$ NMR (100 MHz, $\left.\mathrm{CDCl}_{3}\right): \delta(\mathrm{ppm}) 165.3(\mathrm{C}), 147.4(\mathrm{C}), 133.8(\mathrm{CH})$, 128.6 (CH), $119.3(\mathrm{CH}), 116.1(\mathrm{C}), 114.7(\mathrm{CH}), 99.3(\mathrm{CH}), 67.2\left(\mathrm{CH}_{2}\right), 65.3(\mathrm{CH}), 62.8\left(\mathrm{CH}_{2}\right)$, $\left.33.3\left(\mathrm{CH}_{2}\right), 30.9\left(\mathrm{CH}_{2}\right), 29.3\left(\mathrm{CH}_{2}\right), 25.5\left(\mathrm{CH}_{2}\right), 21.0\left(\mathrm{CH}_{2}\right), 19.9\left(\mathrm{CH}_{2}\right) ; \mathrm{MS}(\mathrm{Q}-\mathrm{TOF}): \mathrm{m} / z\right) 327$ $[\mathrm{M}+\mathrm{Na}]^{+}$. analysis for $\mathrm{C}_{17} \mathrm{H}_{24} \mathrm{~N}_{2} \mathrm{O}_{3}$ (304.18), calcd, C, 67.08; H, 7.95; N, 9.20; found, C, 67.18; $\mathrm{H}, 8.03 ; \mathrm{N}, 9.10$.

\section{Supplementary material available}

Supporting information for this article is available online at http:// http://www.arkat-usa.org. Included are ${ }^{1} \mathrm{H}$ NMR, ${ }^{13} \mathrm{C}$ NMR, DEPT and MS spectra of compound 6. 


\section{Acknowledgments}

N.M., S.M., R.M. and R.Y. are thankful to CSIR for the award of Junior Research Fellowships.

\section{References}

1. Yale, H. L.; Kalkstein, M. J. Med. Chem. 1967, 10, 334.

2. (a) Levin, J. I.; Chan, P. S.; Bailey, T.; Katocs, A. S.; Venkatesan, A. M. Bioorg. Med. Chem. Lett. 1994, 4, 1141. (b) Okumura, K.; Oine, T.; Yamada, Y.; Hayashi, G.; Nakama, M. J. Med. Chem. 1968, 11, 348. (c) Michael, J. P. Nat. Prod. Rep. 2004, 21, 650; (d) Maskey, R. P.; Shaaban, M.; Grun-Wollny, I.; Laatsch, H. J. Nat. Prod. 2004, 67, 1131. (e) Somanadhan, B.; Leong, C.; Whitton, S. R.; Ng, S.; Buss, A. D.; Butler, M. S. J. Nat. Prod. 2011, 74, 1500 .

3. Chinigo, G. M.; Paige, M.; Grindrod, S.; Hamel, E.; Dakshanamurthy, S.; Chruszcz, M.; Minor, W.; Brown, M. L. J. Med. Chem. 2008, 51, 4620.

4. (a) Moore, J. A.; Sutherland, G. J.; Sowerby, R.; Kelly, E. G.; Palermo, S.; Webdter, W. J. Org. Chem. 1969, 887. (b) Sharma, S. D.; Kaur, V. Synthesis 1989, 677.

5. Reddy, B. V. S.; Venkateswarlu, A.; Madan, C.; Vinu, A. Tetrahedron Lett. 2011, 52, 1891.

6. Su, W. K.; Yang, B. B. Aust. J. Chem. 2002, 55, 695.

7. (a) Shi, D. Q.; Rong, L. C.; Wang, J. X.; Zhuang, Q. Y.; Wang, X. S.; Hu, H. W. Tetrahedron Lett. 2003, 44, 3199. (b) Shi, D.; Wang, J.; Rong, L.; Zhuang, Q.; Tu, S.; Hu, H. J. Chem. Res. 2003, 10, 671.

8. Shi, D.-Q.; Rong, L.-C.; Wang, J.-X.; Zhuang, Q.-Y.; Tu, S.-J. Chin. J. Chem. 2004, 22, 743.

9. Khurana, J. M.; Kukreja, G. J. Heterocycl. Chem. 2003, 40, 677.

10. Yoo, C. L.; Fettinger, J. C.; Kurth, M. J. J. Org. Chem. 2005, 70, 6941.

11. Baghbanzadeh, M.; Salehi, P.; Dabiri, M.; Kozehgarya, G. Synthesis 2006, 344.

12. Salehi, P.; Dabiri, M.; Zolfigol, M. A.; Baghbanzadeh, M. Synlett 2005, 1155.

13. Dabiri, M.; Salehi, P.; Otokesh, S.; Baghbanzadeh, M.; Kozehgarya, G.; Mohammadi, A. A. Tetrahedron Lett. 2005, 46, 6123.

14. Salehi, P.; Dabiri, M.; Baghbanzadeh, M.; Bahramnejad, M. Synth. Commun. 2006, 36, 2287.

15. Chen, J. X.; Su, W. K.; Wu, H. Y.; Liu, M. C.; Jin, C. Green Chem. 2007, 9, 972.

16. Chen, J.; Wu, D.; He, F.; Liu, M.; Wu, H.; Ding, J.; Su, W. Tetrahedron Lett. 2008, 49, 3814.

17. Rueping, M.; Antonchick, A. P.; Sugiono, E.; Grenader, K. Angew. Chem. Int. Ed. 2009, 48, 908.

18. Hour, M. J.; Huang, L. J.; Kuo, S. C.; Xia, Y.; Bastow, K.; Nakanishi, Y.; Hamel, E.; Lee, K. H. J. Med. Chem. 2000, 43, 4479. 
19. Abdel-Jalil, R. J.; Voelter, W.; Saeed, M. Tetrahedron Lett. 2004, 45, 3475.

20. Shaabani, A.; Ali Maleki, A.; Mofakham, H. Synth. Commun. 2008, 38, 3751.

21. Cheng, X.; Vellalath, S.; Goddard, R.; List, B. J. Am. Chem. Soc. 2008, 130, 15786.

22. Wang, M.; Zhang, T. T.; Song, Z. G. Chin. Chem. Lett. 2011, 22, 427.

23. Chari, M. A.; Karthikeyan, G.; Pandurangan, A.; Naidu, T. S.; Sathyaseelan, B.; Javaid Zaidi, S. M.; Vinu, A. Tetrahedron Lett. 2010, 51, 2629.

24. (a) Santosh, T. K.; Thirupathi, P.; Kim, S. S. Tetrahedron 2009, 65, 10383. (b) Shiva Kumar, K.; Iqbal, J.; Pal, M. Tetrahedron Lett. 2009, 50, 6244.

25. Kadam, S. T.; Thirupathi, P.; Kim, S. S. Tetrahedron 2009, 65, 10383.

26. Tian, Q.; Zhang, S.; Yu, Q.; He, M.-B.; Yang, J.-S. Tetrahedron 2007, 63, 2142.

27. Das, B.; Banerjee, J.; Ramu, R.; Pal, R.; Ravindranath, N.; Ramesh, C. Tetrahedron Lett. 2003, 44, 5465.

28. Chari, M. A. Tetrahedron Lett. 2011, 52, 6108.

29. Chakraborti, A. K.; Gulhane, R. Chem. Commun. 2003, 1896.

30. Hamel, E.; Lin, C. M.; Plowman, J.; Wang, H.-K.; Lee, K.-H.; Paull, K. D. Biochem. Pharmacol. 1996, 51, 53.

31. Meil, G. L.; Li, L. H.; Buskirk, H. H.; Moxley, T. E. Cancer Chemother. Rep. Part 1 1972, $56,163$.

32. Zeng, L.-Y.; Cai, C. J. Heterocycl. Chem. 2010, 47, 1035.

33. Strakovsk, A.; Avotins, F.; Petrova, M. Rigas Tehniskas Universitates Zinatniskie Raksti, Serija 1: Materialzinatne un Lietiska Kimija 2003, 6, 122.

34. Wang, X.-S.; Ke Yang, J. Z.; Tu, S.-J. J. Comb. Chem. 2010, 12, 417.

35. Shi, D.; Shi, C.; Wang, J.; Rong, L.; Zhuang, Q.; Wang, X. J. Heterocycl. Chem. 2005, 42, 173.

36. Bongini, A.; Cardillo, G.; orena, M.; Sandri, S. Synthesis 1979, 8, 618. 